\title{
Letramento literário e recursos didáticos renovados para um educador cidadão
}

\author{
Marcelo Chiaretto \\ Universidade Federal de Minas Gerais
}

\begin{abstract}
Resumo
O presente artigo pretende investigar como a leitura do texto literário pode capacitar o educador para que este possa escolher e manipular materiais e recursos didáticos aptos a habilitá-lo como um profissional da educação que sabe atuar na escola e na sociedade enquanto ser político corresponsável pelo bem comum.
\end{abstract}

Palavras-chave: Letramento, literatura, recursos didáticos.

\begin{abstract}
This article aims to investigate how the reading of literary texts can empower educators so that they can choose and manipulate materials and learning resources that can enable them to be an education professional who knows how to act in school and in society as a political being that is co-responsible for the common good.

Keywords: Literacy, literature, teaching resources.
\end{abstract}

\section{INTRODUÇÃO}

Em vista dos tempos atuais, compreende-se que o educador necessita de elementos para elaborar uma proposta de ensino civilizadora, humanizadora e politizadora, a fim de poder recuperar e preservar o caráter e a diferença de sua prática docente. Assim, ao educador de toda e qualquer disciplina é fundamental o tempo para o exercício da reflexão com o fim de adquirir saberes, afinar as emoções, conceber um senso de beleza e perceber a complexidade do mundo em suas infinitas redes de relações. Para que esse conjunto de conhecimentos possa ser acessado é necessário o contato cotidiano, ativo e envolvente com textos literários de reconhecida qualidade. Lendo tais textos, o educador pode se habilitar para uma melhor convivência com o próximo, sobretudo pode se capacitar para ser um dinamizador de novos leitores, principalmente entre seus jovens alunos. Torna-se assim fundamental buscar saber se os professores estão de fato lendo literatura nos tempos atuais para assim conseguirem ser dinamizadores ou mediadores de 
textos literários entre seus alunos.

A responsabilidade pela formação literária escolar das séries iniciais no Brasil é atribuída a professores que não têm formação superior ou são egressos de cursos de Pedagogia. Em ambos os casos, esses educadores, em sua maioria, não tiveram formação literária suficiente para serem caracterizados como cidadãos letrados literariamente. Em geral, esses professores não têm acesso a textos literários de sua preferência, lendo apenas literatura infantojuvenil para fins profissionais e não para sua própria vida cultural. Estranhos ao universo literário, esses educadores não têm facilidade de se apresentarem como modelos de leitores para seus alunos, o que constitui um dos agravantes do baixo nível de motivação para a inserção desses alunos no mundo da escrita, seja ela literária ou não. Sendo estranhos ao universo literário, o que esperar de tais educadores no contato com materiais didáticos que requerem cada vez mais um olhar crítico, problematizador e inquiridor?

Os educadores públicos da Educação Básica costumam passar longe da produção literária que circula pelo Brasil, pois não frequentam livrarias, raras no País e ausentes de seus bairros de origem. Geralmente só têm acesso à biblioteca escolar, cujo acervo mais rico se dirige aos alunos-leitores. Quando o governo investe na chamada "Biblioteca do Professor", de preferência adquire livros para a formação continuada, considerando as obras literárias supérfluas quando comparadas às de utilidade para a formação profissional. Trata-se, no entanto, de uma visão restrita das funções da literatura, pois esta pode ser ainda mais útil que um inócuo manual didático formativo, considerando sobretudo o inescapável desempenho cotidiano de um educador às voltas com situações inesperadas, heterogeneidades socioculturais e identidades em mudança.

Em todos os níveis de ensino há uma maioria de educadores que está fora do processo de letramento literário e mereceria inserir-se nessa prática sociocultural. Entretanto, o caso dos educadores das séries iniciais do Ensino Fundamental se apresenta como mais grave, por serem eles os responsáveis pelos primeiros contatos das crianças e jovens com as obras literárias. Não tendo o gosto da leitura e não se apresentando como amantes de livros junto a seus alunos, esses educadores precisam de oportunidades para mudar esse comportamento, assim beneficiando os estudantes, e também melhorando sua própria inserção cultural através do prazer intelectualizado da leitura literária. Ninguém 
ensina o que não sabe, e saber ler literariamente textos de nossa literatura é um passo decisivo para que os educadores se tornem efetivamente formadores de leitores. Da mesma forma, pode-se concluir de modo correlato que saber ler literariamente textos de nossa literatura é um passo decisivo para que os educadores se tornem seres críticos e criativos, aptos a avaliar de modo ético e estético o que deverá compor seu repertório de recursos e materiais didáticos.

Em tais situações, o prazer da leitura dos educadores fará a diferença, já que o letramento literário se tornará parte de um processo de disseminação cultural, e não de imposição ou utilização da literatura apenas como mero pretexto para exercícios de outra natureza. Só um educador-leitor, com um repertório textual rico e diversificado, envolvido verdadeiramente com o universo da literatura, pode formar leitores e organizar seu material didático sem usar estratégias acomodadas ou autoritárias, sem fechar-se no espaço escolar e sem desvincular-se da vida social. E uma formação literária satisfatória apenas se conforma quando o educador reconhece o potencial civilizador e humanizador da leitura literária.

\section{CIVILIZAR}

É sempre relevante exaltar o potencial civilizador da leitura literária, sobretudo quando se está inserido em um tempo histórico em que as concepções de texto literário são tão pouco discutidas fora dos meios acadêmicos. Sobre isso, pode-se dizer que é um engano pensar que, com os livros, as pessoas se tornam objetivamente mais afáveis, mais moderadas, com sentimentos mais harmonizados e educados. O aspecto civilizatório está realmente relacionado com a capacidade que possui a leitura literária de tornar o indivíduo mais dedicado no que tange aos interesses das coletividades, mais atento aos acontecimentos que o cercam, com a sensibilidade mais apurada para poder sentir e pensar melhor sobre si mesmo e, sobretudo, sobre o próximo.

$\mathrm{O}$ ato de civilizar ou a noção de civilização costuma trazer consigo um conjunto de concepções relacionadas a movimentos de colonização e consequentes fábricas de exclusão. Muitas vezes, quando defende o ato civilizatório, é comum alguém imaginar que está defendendo um modelo superior de civilização ou, ainda, que está preconizando a ideia de civilização homogênea aos moldes ocidentais, predominantes e indiscutíveis. 
Nesta oportunidade, busca-se defender uma concepção de civilização e de civilizar que vai à contracorrente do que se compreende na noção comum. $\mathrm{O}$ ato de civilizar será indicado aqui como o de proporcionar mais saberes ao ser humano, saberes que deverão funcionar como armas de combate, em vista de uma realidade hostil que se mantém reproduzindo modelos de desigualdade. Deleuze uma vez propôs que se pode civilizar quando se ensina conceitos maleáveis (DELEUZE, 1994, p.127), conceitos que podem ser reversíveis, transformadores e potentes quando há um intento por estudá-los e manipulá-los. Considerando o contexto escolar, quando um profissional do ensino se propõe a lecionar não simplesmente uma ideia, mas como manipulá-la, ele pode estar civilizando alguém, pode estar tornando um ser mais apto ao trabalho ativo e transformador em uma sociedade civil.

Comumente, concebe-se o ato de civilizar como o ato de fazer uma pessoa sair do estado primitivo, tornando-a assim civil, cortês, instruída, polida, em outras palavras, alguém que teria alcançado uma espécie de progresso pessoal e social. Em contraste com tal posicionamento, convém enfatizar novamente que se procura aqui o ato de civilizar como o ato de instruir alguém, para que esta pessoa possa discutir com competência os conceitos a ela interessantes - incluindo aí os conceitos de "estado primitivo" e de "progresso" obviamente - , assim como conceitos e noções relacionados ao campo da prática docente, por exemplo. Civilizar, assim, implicaria uma técnica militante, com o fim de auxiliar na formação de seres conscientes de seu papel operacional em uma sociedade civil frágil e carente de membros atuantes pelo bem público e comum. A meta seria a defesa da sociedade plural e multifacetada, longe de concepções do que seria o ideal para "todos", o verdadeiro ou a "verdade", pois, como disse outra vez Foucault, "só aparece aos nossos olhos uma verdade que seria riqueza, fecundidade, força doce e insidiosamente universal. E ignoramos, em contrapartida, a vontade de verdade, como prodigiosa maquinaria destinada a excluir" (FOUCAULT, 1996, p.20).

A leitura literária tem um poder incomensurável neste processo "civilizador", e isso acontece por uma razão muito conveniente e relevante. No contato com o texto literário, pode-se perceber a possibilidade de formação de um receptor de textos em pelo menos três escalas. Há inicialmente a formação provável do leitor prosaico, o ser capaz de decodificar as palavras do texto e interpretá-las em nível de leitura vulgar e previsível 
(um leitor apto a ler receitas culinárias, por exemplo). Em um segundo momento, há a formação do leitor crítico, aquele capaz de analisar e discutir sua realidade e a do próximo sob um ponto de vista instabilizador e nevrálgico (um leitor apto à leitura de jornais e textos acadêmicos, por exemplo). Com o texto literário haveria ainda, em um terceiro e crucial momento, a oportunidade de formação do leitor literário, aquele leitor capaz de apropriar-se do texto para abordar sua vida de modo renovado, experimentando assim outros mundos e logrando, enfim, reavaliar sua existência.

A partir de tal gradação, observa-se de modo evidente a capacidade estimável que o texto literário demonstra para civilizar conforme o posicionamento aqui adotado. Ao mergulhar em um texto literário se perdendo e se encontrando em sua leitura, o ser pode disponibilizar para si um poderoso arsenal de disposições técnicas. Seria a aquisição de uma tecnologia apta a instruí-lo eficazmente na arte de manipular ideias e conceitos em prol de uma realidade mais justa e humana. A literatura pode assim civilizar e, a partir desse momento, humanizar.

\section{HUMANIZAR}

De forma contígua e complementar, observa-se que a leitura literária é indispensável no processo de humanização, ou seja, na busca de se confirmar no homem a sua humanidade. Os valores que a sociedade recomenda e exalta ou os que considera maléficos e prejudiciais estão presentes nas diversas manifestações da ficção, da poesia e da ação dramática, por exemplo. Através da leitura literária pode-se vivenciar dialeticamente os problemas, que podem se mostrar de cunho emocional, psíquico, moral, afetivo ou social. Nas mãos do leitor e refletindo a realidade, o livro aberto pode ser fator de inquietação desastrosa, assim como, paradoxalmente, de puro encantamento. Tal paradoxo é responsável pelo arrebatamento do leitor que, em vista das benesses e dos danos, aprende sobre a vida, torna-se mais humano e encontra a humanização ricamente proporcionada pela leitura literária.

A partir de Antonio Candido (CANDIDO, 2004, p.188-189), pode-se concluir a existência de três fases de humanização proporcionada pela leitura literária. Na primeira, a produção literária tira as palavras do nada e as dispõe como todo articulado. A organização da palavra comunica-se assim ao espírito do leitor e o leva, primeiro, a se 
organizar e, em seguida, a organizar o mundo. Toda obra literária pressupõe esta superação do caos, determinada por um arranjo especial das palavras que possibilita propostas múltiplas de sentido.

Em uma segunda fase, a leitura literária humaniza no momento em que satisfaz no leitor a necessidade de conhecer os sentimentos e a sociedade, ajudando-o assim a tomar posição em face deles. Neste caso, a leitura literária é proporcionada por produções nas quais o autor deseja expressamente assumir posição em face de determinados problemas, sejam eles sociais, econômicos, políticos ou existenciais. Em tal situação, não há como o leitor desconsiderar o que lê, não há espaço para superficialidades ou imparcialidades. $\mathrm{O}$ que ocorre são aversões e repugnâncias ou atração arrebatadora e insofismável.

Em uma terceira e última fase, a leitura literária humaniza ao romper as estratificações sociais e permite que o pobre e o rico consigam fruir da literatura conforme suas vontades e capacidades. Isso ocorre sempre que os produtos culturais, sejam eruditos ou populares, estão ao alcance de todos, e não privados, espoliados ou segregados em acordo com uma sociedade iníqua e tortuosa. A literatura pode assim desenvolver na sociedade a esperança de humanidade na medida em que torna as pessoas mais compreensivas e abertas para a natureza, para a sociedade e para o outro.

\section{UMA LITERATURA PARA EDUCADORES}

Como forma de incentivo à leitura literária, o Governo Federal abriu aos cidadãos um site de domínio público no qual podem ser capturados livremente textos da literatura brasileira, cujos autores faleceram há mais de 75 anos. Acontece que tais obras estão escritas para leitores de outra época e sua listagem não guia de fato um leitor sem traquejo, que continua perdido diante de uma literatura desconhecida e inacessível, sem outras referências. Torna-se necessário, portanto, um trabalho de seleção e de reapresentação desse material, para adequá-lo à recepção contemporânea de leitores iniciantes. Os educadores dos anos iniciais necessitam duplamente dessa contribuição da Universidade, pois se trata, ao mesmo tempo, de uma deficiência oculta na formação profissional e na vida pessoal. Tal trabalho deve ser feito por especialistas da Universidade que conheçam literatura e formação de leitores, além de estarem voltados para o exercício em função de demandas sociais de suas habilidades e conhecimentos 
científicos.

As versões dos livros publicadas na época passada podem compor publicações novas, atraentes para leitores iniciantes, como é o caso dos educadores em questão. Asseverar que eles já teriam acesso às obras por elas estarem disponíveis na internet significa ignorar as dificuldades de acesso à rede para os brasileiros com baixo poder aquisitivo. Significa ignorar também as diferenças entre ler na tela do computador e num livro impresso, assim como as necessidades de um leitor iniciante formar sua biblioteca pessoal, com seus textos preferidos disponíveis para leituras que não exigem equipamentos dispendiosos, atualizações constantes, pagamentos de quantias mensais para telefonia ou provedores de banda larga, energia elétrica etc. O livro eletrônico ainda não é um objeto de consumo no Brasil, embora surja na mídia como promessa cara e rara.

Em 2008, o Grupo de Pesquisa e Extensão LIED - Literatura para Educadores -, formado por professores e alunos da UFMG e coordenado pela Profa. Graça Paulino, iniciou suas atividades de organização de obras literárias a serem distribuídas como presentes aos educadores da rede pública envolvidos diretamente com as séries iniciais do Ensino Fundamental. Ligado ao GPELL (Grupo de Pesquisa do Letramento Literário, do Ceale), o Grupo já publicou 6 volumes: Machado Presente em 2008 (em homenagem aos 100 anos de morte do maior escritor brasileiro); Júlia Presente em 2009 (com contos de Júlia Lopes de Almeida); Lima Presente em 2010 (com contos de Lima Barreto); em 2011 Poesia Presente (com uma seleção de poemas de escritores brasileiros); em 2012 o quinto volume, João do Rio Presente, com uma seleção de contos e crônicas do autor mencionado e, no início do ano 2013, foi lançado o sexto volume, Vinícius Presente, com poemas e outros textos de Vinícius de Moraes em comemoração dos 100 anos de vida do "poetinha". Percebe-se que o maior objetivo do grupo é formar leitores entre os educadores, ou melhor, é facilitar o contato de leitores alfabetizadores com uma parte preciosa do patrimônio literário brasileiro. Um contato que se espera prazeroso, uma vez que os contos trabalhados e escolhidos para compor as publicações são textos literários aptos a convidar o leitor a uma leitura ativa, criativa e aprazível.

Sob essa ótica, tais contos selecionados e organizados em volume se constituiriam em materiais e recursos didáticos aptos a capacitar o educador, para que este possa atuar melhor na escola e na sociedade enquanto ser político corresponsável pelo bem comum. 
Seria uma oportunidade absolutamente significativa exaltar o respeito ao direito dos educadores a um lazer literário de qualidade, com a consequente ampliação de seus horizontes culturais no momento em que, mais capacitado pela leitura despretensiosa de um livro, poderia enfim selecionar com mais responsabilidade civil e satisfação os materiais didáticos que darão esteio à sua prática docente.

\section{REFERÊNCIAS}

CANDIDO, A. Direito à literatura. In: Vários Escritos. São Paulo: Duas Cidades, 2004.

DELEUZE, G \& PARNET, C. Diálogos. Lisboa: Relógio D’água, 2004.

FOUCAULT, M. A ordem do discurso. São Paulo: Loyola, 1996.

FOUCAULT, M. Em defesa da sociedade. São Paulo: Martins Fontes, 1999.

MORIN, E. Educação e complexidade: os sete saberes e outros ensaios. São Paulo: Cortez, 2005.

VEIGA-NETO, A. Foucault e a Educação. Belo Horizonte: Autêntica, 2005.

\section{O AUTOR}

Marcelo Chiaretto, PhD, UFMG

E-mail: mchiaretto@uol.com.br 